\title{
Conductive Blends of $\pi$-Conjugated Polymers and Thermoplastic Polymers in Latex Form
}

\author{
Chang-Feng LiU, Tsukasa Maruyama, and Takakazu Yamamoto* \\ Research Laboratory of Resources Utilization, Tokyo Institute of Technology, \\ 4259 Nagatsuta, Midori-ku, Yokohama 227, Japan
}

(Received August 11, 1992)

\begin{abstract}
By using $\mathrm{Fe}(\mathrm{III})-, \mathrm{Fe}(\mathrm{II})-$, or $\mathrm{Cu}(\mathrm{II})-\mathrm{H}_{2} \mathrm{O}_{2}$ oxidation systems, latex form conductive blends of thermoplastic polymer with $\pi$-conjugated polymer, such as polyaniline, polypyrrole, and poly(3-methoxythiophene) were prepared via in situ polymerization in aqueous media containing latex particles. The oxidation system did not give apparent disturbance to the stability of the latex. Morphology study carried out by SEM and TEM showed that the latex polymer particles were uniformly coated by $\pi$-conjugated polymer even at relatively low $\pi$ conjugated polymer content $(4 \mathrm{wt} \%)$. Parameters ( $\mathrm{pH}$, oxidant concentration, etc.) affecting the preparation and morphology of the blends were examined. The blend recovered by removing water by evaporation showed electrical conductivity of $0.02-0.92 \mathrm{~S} \mathrm{~cm}^{-1}$.
\end{abstract}

KEY WORDS Blend / Composite / Polypyrrole / Polyaniline / Poly(3methoxythiophene) / Conductive Polymer / Latex /

Conductive $\pi$-conjugated polymers, such as polyacetylene (PA), poly-p-phenylene (PPP), polypyrrole (PPy), polythiophene (PTh), polyaniline (PAn), and their derivatives, have attracted great interests in recent years. ${ }^{1-5}$ These polymers, after being oxided or reduced by an electron acceptor or donor, possess a conductivity ranging from $10^{-8}$ to $10^{5} \mathrm{~S} \mathrm{~cm}^{-1}$. However, in many cases the conjugated backbone leads to a rigid polymer chain structure and thus make the $\pi$-conjugated polymers intractable. As a result, the applications of these conductive polymers are greatly hindered.

Extensive research efforts have been devoted to improve the processability ${ }^{1,2 c}$ and the mechanical properties of $\pi$-conjugated conductive polymers. One such approach is to make "blends" (polymer-polymer composites), in which the $\pi$-conjugated conductive polymer is blended with a conventional thermoplastic polymer. Various routes have been proposed to prepare such a "blend" material for different $\pi$-conjugated conductive polymers via either a chemical or physical process. Using in situ polymerization method, Galvin and Wnek prepared polymer-polymer composites of polyacetylene and thermoplastic polymers. The approach involved the impregnation of low-density polyethylene (LDPE) matrix with Ziegler-Natta catalysts which allowed the polymerization of acetylene within the LDPE matrix. ${ }^{3}$ Polymers other than LDPE, such as polystyrene, poly(ethylene oxide), poly(methyl methacrylate), and ethylene-vinylacetate copolymer were also found to be suitable for this in situ polymerization approach. ${ }^{7}$ In addition to the polyacetylene/ thermoplastic polymer-polymer composites, poly-p-phenylene (PPP)/poly(phenylene sulfide) (PPS) blends were also prepared by sintering the mixture of PPP and PPS powder. ${ }^{8}$ The $\mathrm{SbCl}_{5}$ doped PPP/PPS blends underwent a transition from insulator to conductor when the PPP content was higher than $20 \mathrm{wt} \%$. 
However, neither doped PPP nor PA was stable when exposed to ambient conditions. Blending of PPP or PA with inert thermoplastic polymers may provide certain protection to the PPP or PA, but can not maintain the stability of the blends over prolonged periods of time. Therefore, a lot of attention has been focused on "blending" thermoplastic polymers with "air stable" conductive polymers, such as polyaniline, polypyrrole, and polythiophene and their derivatives.

Blends of polypyrrole and thermoplastic polymers could be obtained by either electrochemical or chemical polymerization of pyrrole in the matrix of thermoplastic polymer. Generally, electrochemical method has the advantage over chemical polymerization method of producing blends with higher conductivity. However, the final product is restricted by the size and shape of the electrode and would be difficult for large scale - production.

As a consequence, chemical polymerization method was extensively used in the "blending" studies. It can be carried out in several ways: one is via vapor phase polymerization in which the oxidant containing polymer is exposed to pyrrole vapor. Thermoplastic polymers such as polyacrylonitrile, poly(vinyl alcohol), poly(vinyl chloride), and poly(methyl methacrylate) were employed as the matrix polymers. ${ }^{9-11}$ Another route to prepare the blends is to immerse the pyrrole incorporated thermoplastic polymers, such as polystyrene, poly(ethylene terephthalate), and poly(methyl methacrylate), into a solution of an oxidant. ${ }^{12-16}$ By using chemical polymerization method, colloidal systems of polyaniline or polypyrrole with various polymers such as poly(vinylpyridine), polystyrene, and poly(ethylene oxide) were also investigated. ${ }^{17-19}$ Furthermore, conductive fibers were developed in which fibers of nylons, $\operatorname{poly}(p$ phenylene terephthalamide) (PPTA or Kevlar) and polyester were coated by polypyrrole or polyaniline. ${ }^{20,21}$ Very recently, work related to polyaniline-copolymer composites using a latex system was reported, ${ }^{22}$ however, the latex system was unstable and the composites were obtained only as precipitates, probably due to the large amount of oxidizing agent such as $\left(\mathrm{NH}_{4}\right)_{2} \mathrm{~S}_{2} \mathrm{O}_{8}$ used for the oxidation polymerization of aniline.

In this paper we report the preparation of conductive polymer blends of thermoplastic polymer and $\pi$-conjugated polymer, such as polyamiline, polypyrrole, and poly(3-methoxythiophene). The blends were produced via in situ oxidative polymerization using a $\mathrm{Fe}(\mathrm{III})-$, $\mathrm{Fe}(\mathrm{II})-$, or $\mathrm{Cu}(\mathrm{II})-\mathrm{H}_{2} \mathrm{O}_{2}$ oxidation system, which was developed recently by Yamamoto $e t$ $a l^{23}$ and was proved to be effective for the synthesis of polyaniline and its derivatives. This new method enabled us to accomplish the oxidative polymerization of pyrrole or aniline at a very low $\mathrm{Fe}$ concentration $\left(1 \times 10^{-3} \mathrm{~mol} \mathrm{dm}^{-3}\right)$ and a low ionic strength, thus minimizing disturbance to the stability of the polymer latex.

\section{EXPERIMENTAL}

\section{Materials}

Pyrrole was distilled and stored under $\mathrm{N}_{2}$ in refrigerator before use. Aniline (Kanto Chemical Co., Ind.), $\mathrm{FeCl}_{3} \cdot 6 \mathrm{H}_{2} \mathrm{O}$ (Koso Chemical Co., Inc.), $\mathrm{FeSO}_{4} \cdot 7 \mathrm{H}_{2} \mathrm{O}$ (Koso Chemical Co., Inc.), $\mathrm{CuSO}_{4} \cdot 5 \mathrm{H}_{2} \mathrm{O}$ (Koso Chemical Co., Inc.), and $\mathrm{Cu}\left(\mathrm{ClO}_{4}\right)_{2} \cdot 6 \mathrm{H}_{2} \mathrm{O}$ (Kanto Chemical Co., Inc.) were used as received. Water was deionized. Hydrogen peroxide (31\%, Mitsubishi Gas Chemical Co., Inc.) was diluted to $15 \mathrm{wt} \%$. Two grades of polymer latex from Japan Synthetic Rubber (JSR), Inc., JSR640 and JSR SX863, were diluted to $5 \mathrm{wt} \%$ polymer content for the use in this work. Properties of polymer latex are listed in Table I.

The polymer of latex JSR 640, styrenebutadiene rubber (SBR), is a copolymer of styrene, butadiene, and methyl methacrylate with possibly a small amount of methacrylic 
Table I. Properties of the polymer latex

\begin{tabular}{|c|c|c|c|c|c|}
\hline & Composition $^{\mathrm{a}}$ & \multirow{2}{*}{$\begin{array}{l}\text { Average particle } \\
\text { size } / \mathrm{nm}\end{array}$} & \multirow{2}{*}{ Polym. density } & $T_{\mathbf{g}}$ & \multirow{2}{*}{$\mathrm{pH}$} \\
\hline & $w t \%$ & & & ${ }^{\circ} \mathrm{C}$ & \\
\hline JSR640 & $\begin{array}{c}\mathrm{BD} / \mathrm{ST} / \mathrm{MMA} / \mathrm{COOH} \\
14 / 71 / 12 / 3\end{array}$ & 240 & 1.05 & 50 & 8.8 \\
\hline JSR & ST/MMA/DVB/COOH & 350 (outside) & & & \\
\hline SX863 & $10 / 50 / 35 / 5$ & 230 (inside) & 0.76 & b & 8.0 \\
\hline
\end{tabular}

a $\mathrm{BD}=$ butadiene; $\mathrm{ST}=$ styrene; $\mathrm{MMA}=$ methyl methacrylate; $\mathrm{COOH}=$ carboxylic acid (methacrylic acid); $\mathrm{DVB}=$ divinyl benzene.

b Not obtainable due to the high degree of crosslinking.

Table II. Polymerization conditions

\begin{tabular}{|c|c|c|c|c|c|}
\hline \multirow{2}{*}{ Run } & \multirow{2}{*}{$\begin{array}{c}\text { Starting Monomer/ } \\
\text { polymer ratio, wt } / w^{a}\end{array}$} & \multirow{2}{*}{\begin{tabular}{|l} 
Monomer \\
$\mathrm{mol} \mathrm{dm}^{-3}$
\end{tabular}} & \multirow{2}{*}{$\frac{\text { Catalyst }^{\mathrm{b}}}{\mathrm{moldm}^{-3}}$} & \multirow{2}{*}{$\frac{\mathrm{H}_{2} \mathrm{O}_{2}}{\mathrm{~mol} \mathrm{dm}}$} & \multirow{2}{*}{$\frac{\text { Acid }^{\mathrm{c}}}{\mathrm{moldm} \mathrm{m}^{-3}}$} \\
\hline & & & & & \\
\hline 1. & $\mathrm{Py} / \mathrm{SBR}=4 / 100$ & 0.03 & A, 0.0012 & 0.035 & E, 0.18 \\
\hline 2. & $\mathrm{Py} / \mathrm{SBR}=8 / 100$ & 0.06 & A, 0.0012 & 0.07 & E, 0.18 \\
\hline 3. & $\mathrm{Py} / \mathrm{SBR}=16 / 100$ & 0.12 & $\mathrm{~A}, 0.0012$ & 0.14 & E, 0.18 \\
\hline 4. & $\mathrm{Py} / \mathrm{SBR}=32 / 100$ & 0.24 & A, 0.0012 & 0.28 & E, 0.18 \\
\hline 5. & $\mathrm{Py} / \mathrm{SBR}=60 / 100$ & 0.45 & A, 0.0012 & 0.46 & E, 0.18 \\
\hline 6. & $\mathrm{Py} / \mathrm{SX} 863=8 / 100$ & 0.03 & $\mathrm{~A}, 0.0012$ & 0.035 & E, 0.18 \\
\hline 7. & $\mathrm{Py} / \mathrm{SX} 863=16 / 100$ & 0.06 & A, 0.0012 & 0.07 & E, 0.18 \\
\hline 8. & $\mathrm{An} / \mathrm{SBR}=18 / 100$ & 0.09 & $\mathrm{~A}, 0.0012$ & 0.09 & E, 0.18 \\
\hline 9. & $\mathrm{An} / \mathrm{SBR}=32 / 100$ & 0.18 & $\mathrm{~A}, 0.0012$ & 0.17 & E, 0.30 \\
\hline 10. & $3 \mathrm{Mth} / \mathrm{SBR}=11 / 100$ & 0.05 & $\mathrm{~B}, 0.05$ & - & E, 0.18 \\
\hline 11. & $3 \mathrm{Mth} / \mathrm{SBR}=25 / 100$ & 0.11 & $\mathrm{~B}, 0.08$ & - & E, 0.18 \\
\hline 12. & $\mathrm{Py} / \mathrm{SBR}=12 / 100$ & 0.09 & $C, 0.0012$ & 0.094 & $F, 0.05$ \\
\hline 13. & $\mathrm{Py} / \mathrm{SBR}=24 / 100$ & 0.18 & $\mathrm{C}, 0.0012$ & 0.19 & $\mathrm{~F}, 0.05$ \\
\hline 14. & $\mathrm{Py} / \mathrm{SBR}=22 / 100$ & 0.16 & $\mathrm{~B}, 0.0012$ & 0.15 & E, 0.18 \\
\hline 15. & $\mathrm{Py} / \mathrm{SBR}=21 / 100$ & 0.16 & $\mathrm{D}, 0.0012$ & 0.15 & E, 0.18 \\
\hline
\end{tabular}

${ }^{\text {a }}$ Py=pyrrole; $\mathrm{An}=$ aniline; $3 \mathrm{Mth}=3$-methoxythiophene; $\mathrm{SBR}=$ styrene butadiene rubber, $\mathrm{SX} 863=$ polymer of JSR SX863 latex.

b $\mathrm{A}=\mathrm{FeCl}_{3} ; \mathrm{B}=\mathrm{Cu}\left(\mathrm{ClO}_{4}\right)_{2} ; \mathrm{C}=\mathrm{FeSO}_{4} ; \mathrm{D}=\mathrm{CuSO}_{4}$.

c $\mathrm{E}=\mathrm{HBr} ; \mathrm{F}=\mathrm{H}_{2} \mathrm{SO}_{4}$.

acid. It is believed that the surfactant system contains alkyl sulfonic salt.

\section{Preparation of the Conductive Polymer Blends}

Preparation of the blends was carried out by in situ polymerization at ambient conditions. Monomer (pyrrole or aniline), $\mathrm{H}_{2} \mathrm{O}_{2}$ $(15 \mathrm{wt} \%)$, and acid $\left(\mathrm{HBr}(47 \%)\right.$ or dil. $\left.\mathrm{H}_{2} \mathrm{SO}_{4}\right)$ were added into the diluted latex, respectively. Aniline was completely dissolved in the acidic medium. Pyrrole had a limited solubility in aqueous medium $(8 \mathrm{~g}$ pyrrole $/ 100 \mathrm{~g}$ water, $25^{\circ} \mathrm{C}$ ), however, moderate stirring led to smooth polymerization of pyrrole on the latex particles. As soon as the monomer was completely dissolved or well dispersed in the solution, a small amount of $0.1 \mathrm{M} \mathrm{FeCl}_{3}$ (aq) was injected into the stirred solution and the oxidative polymerization reaction was allowed to proceed for $4 \mathrm{~h}$. Once $\mathrm{FeCl}_{3}$ was added, the color of the reaction mixture changed from white to black (in the case of pyrrole) 
or green (in the case of aniline) within 20 $30 \mathrm{~min}$. At the end of the reaction, polymer blends were obtained directly in latex form, which was stable and did not show precipitation for days at room temperature. Powder of the composite was obtained by evaporating the water content under vacuum. Detailed polymerization conditions of each blend systems are listed in Table II, in which the starting monomer/polymer ratio is the weight ratio between the thermoplastic polymer in latex, and the added monomer such as aniline, pyrrole and 3-methoxythiophene prior to the polymerization.

The conditions of polymerization of 3methoxythiophene onto SBR (JSR640) latex particles differ slightly from the above procedures. Since 3-methoxythiophene has very limited solubility in water, the polymerization was carried out in a mixture of acetonitrile and water $\left(\mathrm{CH}_{3} \mathrm{CN} / \mathrm{H}_{2} \mathrm{O}=50 / 50\right.$, wt. ratio $)$ at $75^{\circ} \mathrm{C}$ for $4 \mathrm{~h} . \mathrm{Cu}\left(\mathrm{ClO}_{4}\right)_{2}$ was used as oxidant according to the method reported in the literature. ${ }^{24}$

\section{Measurements}

Morphology study of the blends was conducted on Scanning Electronic Microscope (SEM, JEOL) and Transmission Electronic Microscope (TEM, JEOL), respectively. Unstained samples were used for TEM. Conductivity of the blends was measured by using a compressed disc $(r=4.5 \mathrm{~mm}$, thickness $=$ $1 \mathrm{~mm})$ pressed under $200 \mathrm{~kg} \mathrm{~cm}^{-2}$. A fourprobe tester, Loresta-AP (Mitsubishi Petrochemical Co.), was also used for the measurements of conductivity of blend films pressed under $200 \mathrm{~kg} \mathrm{~cm}^{-2}$ and $190-200^{\circ} \mathrm{C}$.

\section{RESULTS AND DISCUSSION}

\section{Preparation of the Composites}

Table III lists the yield of $\pi$-conjugated polymer, the results of element analysis, polymer blend compositions calculated from the element analysis and the conductivity of the blends.

For the oxidative polymerization of pyrrole, ferric chloride has provided a convenient means and has been used extensively for the synthesis of polypyrrole. Pron et al. ${ }^{25}$ proposed the following scheme for the reaction:

$$
\begin{aligned}
& 4 \mathrm{C}_{4} \mathrm{H}_{5} \mathrm{~N}+9 \mathrm{Fe}(\mathrm{III})\left(\mathrm{H}_{2} \mathrm{O}\right)_{6} \mathrm{Cl}_{3} \rightarrow \\
& \quad\left[\mathrm{C}_{4} \mathrm{H}_{3} \mathrm{~N}\right]_{4} \mathrm{Cl}+8 \mathrm{HCl}+9 \mathrm{Fe}(\mathrm{II}) \mathrm{Cl}_{2} \cdot 6 \mathrm{H}_{2} \mathrm{O}
\end{aligned}
$$

in which an optimum amount of $\mathrm{FeCl}_{3}$, $2.25 \mathrm{~mol}$ of $\mathrm{FeCl}_{3}$ per mole of pyrrole monomer, was suggested, and indeed this ratio was proved to give the maximum yield. ${ }^{5}$ Unfortunately, such a high $\mathrm{FeCl}_{3}$ content can not be employed in this study due to the interaction between ferric chloride and the surfactant systems of the polymer latex. In the case of JSR 640 and JSR SX863, which were the two most stable latex systems among the ones tested, a $\mathrm{FeCl}_{3}$ concentration higher than $10^{-3} \mathrm{~mol} \mathrm{dm}^{-3}$ affected the stability of the latex and cause precipition of the latex particles.

In order to proceed with the polymerization while keeping the latex stability intact, a second oxidant, hydrogen peroxide $\left(\mathrm{H}_{2} \mathrm{O}_{2}\right)$, was introduced to the oxidation system. With a much higher standard electrode potential $\left(\mathrm{H}_{2} \mathrm{O}_{2}+2 \mathrm{H}^{+}+2 \mathrm{e} \rightarrow 2 \mathrm{H}_{2} \mathrm{O}, E^{0}=1.55 \mathrm{~V}\right), \mathrm{H}_{2} \mathrm{O}_{2}$ could readily oxide $\mathrm{Fe}(\mathrm{II})\left(\mathrm{Fe}^{3+}+\mathrm{e} \rightarrow \mathrm{Fe}^{2+}, E^{0}=\right.$ $0.773 \mathrm{~V}$ ) back to $\mathrm{Fe}(\mathrm{III})$ (eq 2) and therefore maintained the level of $\mathrm{Fe}$ (III) concentration throughout the entire polymerization reaction.

$$
2 \mathrm{Fe}^{2+}+\mathrm{H}_{2} \mathrm{O}_{2}+2 \mathrm{H}^{+} \rightarrow 2 \mathrm{Fe}^{3+}+2 \mathrm{H}_{2} \mathrm{O}
$$

From eq 1 and 2, it is concluded that in order to reach a $2: 1 \mathrm{Fe}$ (III) to pyrrole molar ratio while using only a low $\mathrm{Fe}(\mathrm{III})$ concentration to start with, a $1: 1 \mathrm{H}_{2} \mathrm{O}_{2}$ to pyrrole molar ratio is necessary. By using $\mathrm{Fe}(\mathrm{III})-$ $\mathrm{H}_{2} \mathrm{O}_{2}$ oxidation system, no precipitation was observed in the latex at the end of the reaction. $\mathrm{Fe}(\mathrm{II})$ compounds like $\mathrm{FeSO}_{4}$ and $\mathrm{Cu}(\mathrm{II})$ compounds such as $\mathrm{Cu}\left(\mathrm{ClO}_{4}\right)_{2}$ and $\mathrm{CuSO}_{4}$ were also effective for the preparation of the 
Table III. Element analysis results, blend composition, and conductivity

\begin{tabular}{|c|c|c|c|c|c|c|c|c|}
\hline \multirow{2}{*}{ Run } & \multirow{2}{*}{$\begin{array}{l}\text { Starting monomer/ } \\
\text { polymer ratio, wt/wt }\end{array}$} & \multicolumn{4}{|c|}{ Element analysis ${ }^{\mathrm{a}} / \%$} & \multirow{2}{*}{$\begin{array}{l}\text { Yield of PPy, PAn } \\
\text { or poly }(3 \mathrm{Mth}) / \%\end{array}$} & \multirow{2}{*}{$\begin{array}{c}\text { Blend } \\
\text { composition }^{b}\end{array}$} & \multirow{2}{*}{$\sigma / \mathrm{S} \mathrm{cm}^{-1 \mathrm{c}}$} \\
\hline & & $\mathrm{C}$ & $\mathrm{H}$ & $\mathbf{N}$ & $\mathrm{S}$ & & & \\
\hline 1. & $\mathrm{Py} / \mathrm{SBR}=4 / 100$ & 78.9 & 7.4 & 0.6 & - & 72.5 & $\mathrm{PPy} / \mathrm{SBR}=2.9 / 100$ & 0.02 \\
\hline 2. & $\mathrm{Py} / \mathrm{SBR}=8 / 100$ & 75.1 & 7.1 & 1.0 & - & 61.3 & $\mathrm{PPy} / \mathrm{SBR}=4.9 / 100$ & 0.08 \\
\hline 3. & $\mathrm{Py} / \mathrm{SBR}=16 / 100$ & 75.0 & 7.2 & 1.8 & - & 56.9 & $\mathrm{PPy} / \mathrm{SBR}=9.1 / 100$ & 0.20 \\
\hline 4. & $\mathrm{Py} / \mathrm{SBR}=32 / 100$ & 72.4 & 6.8 & 2.5 & - & 40.9 & $\mathrm{PPy} / \mathrm{SBR}=13.1 / 100$ & $0.71(0.65)$ \\
\hline 5. & $\mathrm{Py} / \mathrm{SBR}=60 / 100$ & 64.6 & 5.8 & 5.6 & - & 58.5 & $\mathrm{PPy} / \mathrm{SBR}=35.1 / 100$ & $0.92(0.84)$ \\
\hline 6. & $\mathrm{Py} / \mathrm{SX} 863=8 / 100$ & 66.7 & 7.1 & 1.0 & - & 61.3 & $\mathrm{PPy} / \mathrm{SX} 863=4.9 / 100$ & 0.02 \\
\hline 7. & $\mathrm{Py} / \mathrm{SX} 863=16 / 100$ & 66.4 & 7.4 & 1.8 & - & 56.9 & $\mathrm{PPy} / \mathrm{SX} 863=9.1 / 100$ & 0.23 \\
\hline 8. & $\mathrm{An} / \mathrm{SBR}=18 / 100$ & 71.4 & 6.7 & 1.9 & - & 53.9 & $\mathrm{PAn} / \mathrm{SBR}=9.7 / 100$ & 0.20 \\
\hline 9. & $\mathrm{An} / \mathrm{SBR}=36 / 100$ & 64.1 & 6.1 & 3.0 & - & 44.7 & $\mathrm{PAn} / \mathrm{SBR}=16.1 / 100$ & 0.21 \\
\hline 10. & $3 \mathrm{Mth} / \mathrm{SBR}=11 / 100$ & 64.4 & 6.5 & - & 3.2 & - & - & $1 \times 10^{-4}$ \\
\hline 11. & $3 \mathrm{Mth} / \mathrm{SBR}=25 / 100$ & 70.8 & 6.8 & - & 3.9 & - & - & $1.4 \times 10^{-4}$ \\
\hline 12. & $\mathrm{Py} / \mathrm{SBR}=12 / 100$ & 72.0 & 6.9 & 1.6 & - & 66.7 & $\mathrm{PPy} / \mathrm{SBR}=8.0 / 100$ & 0.03 \\
\hline 13. & $\mathrm{Py} / \mathrm{SBR}=24 / 100$ & 68.7 & 6.4 & 2.7 & - & 59.6 & $\mathrm{PPy} / \mathrm{SBR}=14.3 / 100$ & 0.35 \\
\hline 14. & $\mathrm{Py} / \mathrm{SBR}=22 / 100$ & 71.1 & 6.5 & 2.4 & - & 56.8 & $\mathrm{PPy} / \mathrm{SBR}=12.5 / 100$ & $0.80(0.73)$ \\
\hline 15. & $\mathrm{Py} / \mathrm{SBR}=21 / 100$ & 71.6 & 6.6 & 2.5 & - & 62.4 & $\mathrm{PPy} / \mathrm{SBR}=13.1 / 100$ & 0.08 \\
\hline
\end{tabular}

a Since the composite contains oxygen originated from MMA and vinylic acid (Table I) as well as possibly from surfactant, the value does not reach 100

${ }^{b}$ wt/wt ratio calculated based on the analytical value of $N(N$ value): $P P y /[P P y+S B R($ or $S X 863)]=N$ value $\times(65 / 14)$.

c Data in the parentheses are conductivity measured by four-point method. 
latex without losing the stability of the latex. Obtaining the stable latex of conductive composites will provide new applications for the conductive polymers.

In addition to maintaining the stability of the latex, the use of $\mathrm{Fe}$ (II)- and $\mathrm{Fe}$ (III) $-\mathrm{H}_{2} \mathrm{O}_{2}$ oxidation system may also facilitate the coating of polypyrrole onto the surface of latex particles. During polymerization, once the pyrrole polymer or the cation radicals of pyrrole oligomers were generated, two competing absorption processes seemed to start in the reaction mixture. One was the absorption between polypyrrole chains (or cation radicals of pyrrole oligomers or polymer themselves), and the other was the incorporation of polypyrrole or pyrrole oligomers cation radicals onto the surface of latex particles. If a 2.25:1 $\mathrm{Fe}(\mathrm{III})$ to pyrrole molar ratio as suggested in the literature was adopted, the high concentration of $\mathrm{Fe}$ (III) would lead to a large number of cation radicals and therefore a rapid polymerization reaction, which would promote the chance of aggregation between polypyrrole polymer chains and thus might create undesirable isolated polypyrrole clusters. The use of the $\mathrm{Fe}(\mathrm{II})-$ and $\mathrm{Fe}(\mathrm{III})-\mathrm{H}_{2} \mathrm{O}_{2}$ oxidation system seems to force the oxidative polymerization to proceed at a low $\mathrm{Fe}(\mathrm{III})$ concentration thereby limiting the cation radical numbers throughout the reaction and controlling the polymerization at a slow rate. As the result of a slow polymerization rate, polypyrrole or pyrrole oligomers would tend to adhere more extensively onto the surface of the latex polymer particles.

Another important factor to be considered for the preparation of the blends is the $\mathrm{pH}$ level of the reaction mixture. The commercial grades of latex JSP640 and JSP SX863 have a $\mathrm{pH}$ of $8-9$, and no oxidative polymerization occurred in such a high $\mathrm{pH}$ environment. This can probably be attributed to two reasons. One is that the chain growth of polypyrrole is realized by the approach of pyrrole cation radical and the cation radicals of pyrrole oligomers or polymer, which can proceed smoothly only in an acidic media. The other reason is that $\left[\mathrm{Fe}\left(\mathrm{H}_{2} \mathrm{O}\right)_{6}\right]^{3+}$ exist only at very low $\mathrm{pH}$ and can be easily hydrolyzed even at a $\mathrm{pH}$ of $2-3$ to $\left[\mathrm{Fe}\left(\mathrm{H}_{2} \mathrm{O}\right)_{5}(\mathrm{OH})\right]^{2+}$ and $\left[\mathrm{Fe}\left(\mathrm{H}_{2} \mathrm{O}\right)_{4}(\mathrm{OH})_{2}\right]^{+}$. (eq 3 and 4$)$

$$
\begin{gathered}
\mathrm{Fe}\left(\mathrm{H}_{2} \mathrm{O}\right)_{6}^{3+} \rightarrow\left[\mathrm{Fe}\left(\mathrm{H}_{2} \mathrm{O}\right)_{5}(\mathrm{OH})\right]^{2+}+\mathrm{H}^{+} \\
{\left[\mathrm{Fe}\left(\mathrm{H}_{2} \mathrm{O}\right)_{5}(\mathrm{OH})\right]^{2+}} \\
\rightarrow\left[\mathrm{Fe}\left(\mathrm{H}_{2} \mathrm{O}\right)_{4}(\mathrm{OH})_{2}\right]^{+}+\mathrm{H}^{+}
\end{gathered}
$$

It was pointed out by Gregory ${ }^{21}$ that as a weak base, pyrrole would be more readily approached by $\mathrm{Fe}\left(\mathrm{H}_{2} \mathrm{O}\right)_{6}^{3+}$ at a low $\mathrm{pH}$. At a high $\mathrm{pH}$, the $\left[\mathrm{Fe}\left(\mathrm{H}_{2} \mathrm{O}\right)_{5}(\mathrm{OH})\right]^{2+}$ and $[\mathrm{Fe}-$ $\left.\left(\mathrm{H}_{2} \mathrm{O}\right)_{4}(\mathrm{OH})_{2}\right]^{+}$formations made the approach of $\mathrm{Fe}(\mathrm{III})$ to pyrrole monomer more difficult and thus slowed down the oxidative polymerization of pyrrole. In this study the $\mathrm{pH}$ of the reaction mixture was adjusted by adding acids such as $\mathrm{HBr}$ or $\mathrm{H}_{2} \mathrm{SO}_{4}$.

The oxidative polymerization of poly(3methoxythiophere) follows a similar mechanism of that of polypyrrole, while the oxidative reaction of aniline is believed to undergo a different route. The latex of poly(3-methoxythiophene) blends were not so stable as those of polypyrrole or polyaniline blends, which was probably due to the $\mathrm{CH}_{3} \mathrm{CN}$ content in the reaction mixture.

\section{Characterization and Properties of the Com- posites}

Figures 1 and 2 show SEM and TEM of the blends. At a low starting pyrrole concentration, the latex particles were coated smoothly and uniformly by a layer of polypyrrole, as it can be seen in Figure 1b. As the polypyrrole content increased, polypyrrole started to accumulate on the particle surface in an irregular pattern (Figure 1d).

The presence of polymer latex particles, which have enormous surface areas, have strong impact on the morphology of $\pi$ conjugated polymers. Figure 3 is the TEM of polypyrrole polymerized under the identical 


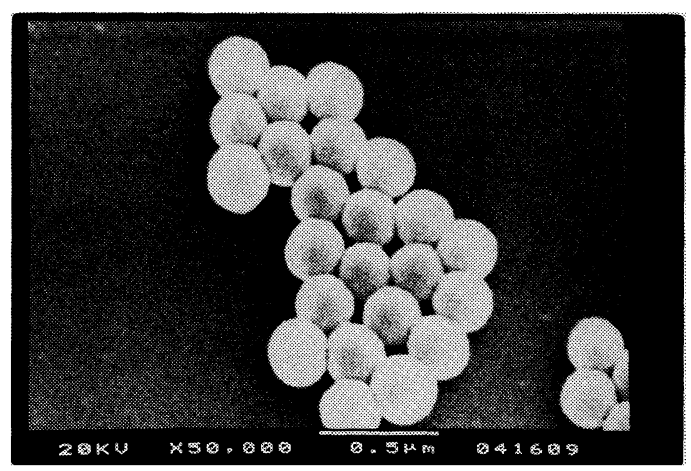

(a)

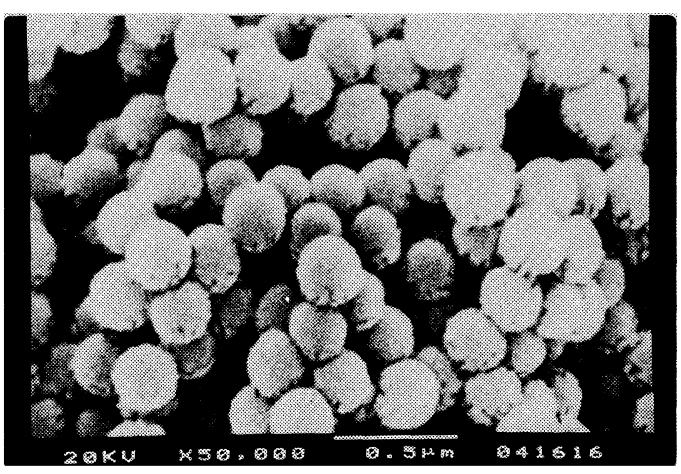

(b)

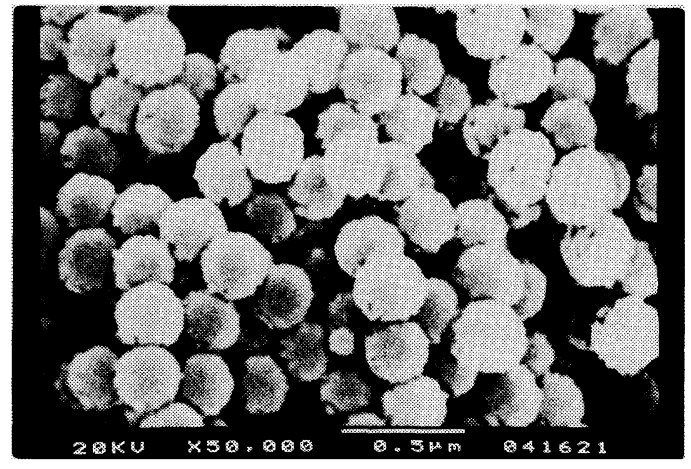

(c)

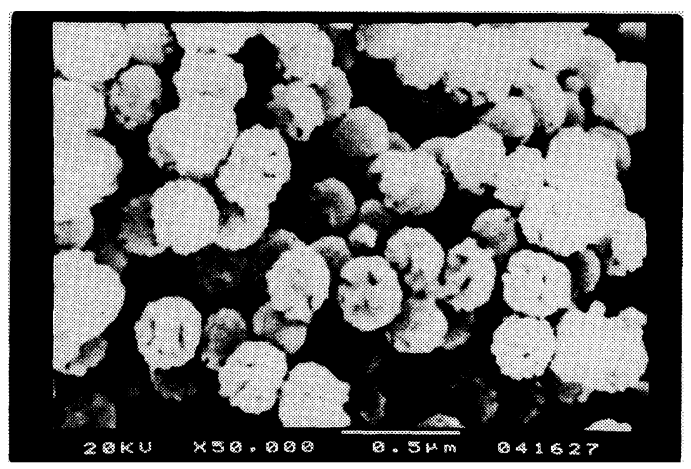

(d)

Figure 1. Comparison of SEM of (a) SBR (JSR640) and (b) - (d) SBR-polypyrrole blends ((b) $100: 2.9$, (c) $100: 4.9$, (d) $100: 9.1 \mathrm{wt}$ ratio, corresponding to Runs No. 1, 2, and 3, respectively, in Tables II and III) recovered from the latex. $\times 50000$

conditions of Run No. 2 in Table II, but without the presence of polymer latex. It shows clusters of globules of polypyrrole with voids in between (Figure 3a). Under higher magnification $(\times 100000)$, it can be seen that the cluster seems to be composed of small polypyrrole globules with rather uniform size of about $50 \mathrm{~nm}$ (Figure $3 \mathrm{~b}$ ).

Without the presence of latex particles, the polymerization of pyrrole monomer can be initiated and proceeded only in the aqueous solution in which pyrrole monomer was completely dissolved. The pyrrole oligomers or polymer (or the cation radicals of pyrrole oligomers or polymer), once formed, would become insoluble in water and tend to aggregate with each other into polypyrrole globules. This absorption is a physical process and is determined by the physical interactions between the polypyrrole polymer chains. TEM results suggested that at first the aggregation of polymer chains forms polypyrrole globules of $50 \mathrm{~nm}$ size and then these small polypyrrole particles further combine into a cluster structure (Figure 3a).

A rather different morphology was observed when pyrrole was polymerized in the presence of polymer latex particles. In this case, pyrrole monomers could exist both on the surface of the latex particles and in the aqueous solution 


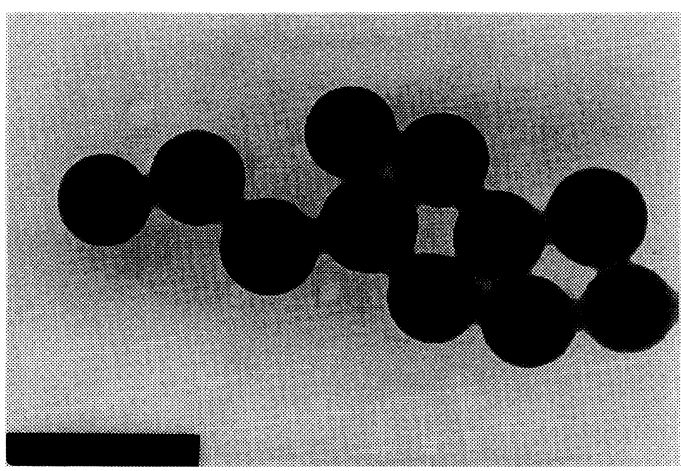

(a)

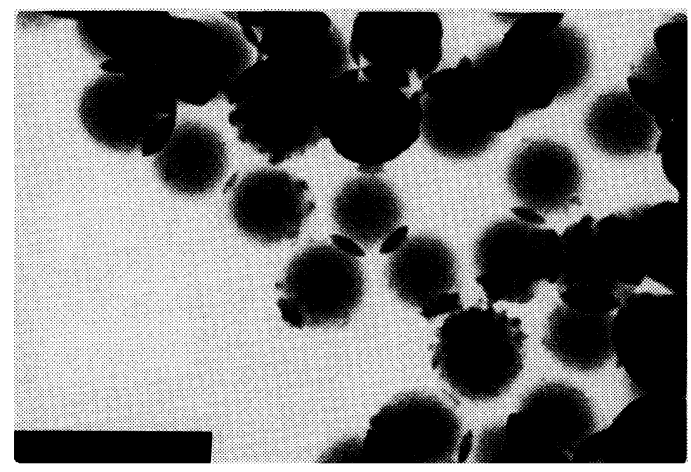

(b)

Figure 2. Comparison of TEM (a) SBR (JSR640) and (b) SBR-polypyrrole blend (100:9.1 wt ratio, Run No. 3 in Tables II and III). $\times 50000$

prior to the polymerization. Therefore, as the iron compound was injected into the solution, the polymerization could be initiated either in the solution or on the latex particle surface. Due to the insolubility in water and the low polymerization rate, polypyrrole or pyrrole oligomers (or the cation radicals of pyrrole oligomers or polymer), once generated, would be driven from the solution onto the latex particle surface. SEM and TEM showed no presence of isolated polypyrrole particles, indicating that most of the polypyrrole was incorporated onto the surface of the latex particles.

The absorption of polypyrrole and polyani-

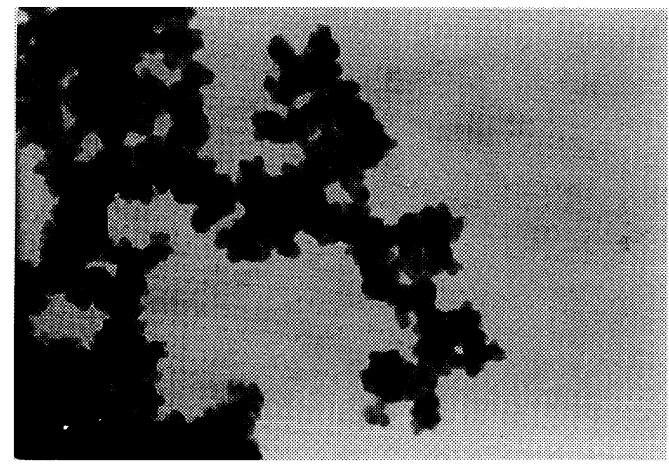

(a)

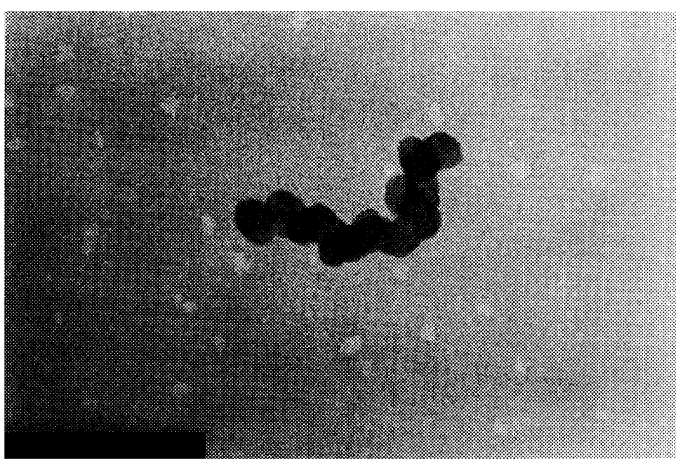

(b)

Figure 3. TEM of polypyrrole prepared in aqueous media without the latex particles. (a) $\times 50000$; (b) $\times 100000$.

line onto the thermoplastic polymer surface is considered to be mainly a physical process, with a possible formation of hydrogen bonding between --NH- of polypyrrole or polyaniline and the - $\mathrm{CO}$ - group of methacrylic acid on the latex particle surface. Based on the SEM and TEM results, the absorption seems to undergo two steps. The first was driven by the physical interaction between pyrrole oligomers or polymer and the latex particle surface, and as a result, a thin polypyrrole layer of $2-3 \mathrm{~nm}$ was formed on the surface of the latex particles. At a low starting pyrrole concentration, such as $4 \mathrm{wt} \%$ in Run No. 1 in Table II, only such a thin monolayer of 
polypyrrole was observed (Figure 1b). At higher polypyrrole content, further deposition of polypyrrole would accumulate on this thin polypyrrole layer (Figure 1d), and create globule like polypyrrole particles attaching to the surface of the first polypyrrole layer. The second step is driven by the physical interaction between polypyrrole polymer chains, although in the case of the absorption of cation radicals of pyrrole oligomers or polymer on the latex surface, chemical absorption may occur between the cation radicals of pyrrole, pyrrole oligomers and polymer.

The uniform coating of $\pi$-conjugated polymer on the latex particle surface took the advantage of the conductive characteristic of the $\pi$-conjugated polymer in an efficient way. With only $2.9 \mathrm{wt} \%$ polypyrrole content, the material changed from an insulator (styrenebutadiene rubber, polymer of JSR640) to a blend with a conductivity of $0.02 \mathrm{~S} \mathrm{~cm}^{-1}$ (Table III, Run No. 1). The conductivity of the blends increased rapidly from $2.9 \mathrm{wt} \%$ to $9.1 \mathrm{wt} \%$ of polypyrrole content, and then gradually leveled off at higher polypyrrole content.

The conductive polymer blends are stable in air. For example, the conductivity of samples made under similar condition of Run No. 3 in Table II was $0.20 \mathrm{~S} \mathrm{~cm}^{-1}, 0.19 \mathrm{~S} \mathrm{~cm}^{-1}$, and $0.19 \mathrm{~S} \mathrm{~cm}^{-1}$ after exposing to air at room temperature for 1,5 , and 10 days, respectively. This is probably due to the fact that the $\mathrm{Fe}(\mathrm{II})-, \mathrm{Fe}(\mathrm{III})-$, and $\mathrm{Cu}(\mathrm{II})-\mathrm{H}_{2} \mathrm{O}_{2}$ catalyst systems used for the oxidative polymerization contained a very small amount of metal ion (Table II), and therefore left a extremely low metal ion residue in the polymer blends.

The ultimate goal of this study was to develop conductive polymer blends which could be either used directly in latex form as a conductive coating material or be processed by conventional thermoplastic molding equipment into various desirable forms. The processability of these blends is currently under investigation. The effect of the surfactant of the polymer latex which may affect the polymerization, absorption process, and the doping of $\pi$-conjugated polymers, is also the subject of further study.

\section{CONCLUSION}

Conductive blends of thermoplastic polymers and $\pi$-conjugated polymers, such as polyaniline, polypyrrole and poly(3-methoxythiophene), were prepared via in situ polymerization using $\mathrm{Fe}(\mathrm{II})-, \mathrm{Fe}(\mathrm{III})-$, and $\mathrm{Cu}(\mathrm{II})-$ $\mathrm{H}_{2} \mathrm{O}_{2}$ oxidative systems in the presence of polymer latex. The use of the oxidative system limit the interaction between catalyst system and the surfactant system of the latex and minimize the disturbance to the stability of the latex. SEM and TEM results indicated that uniform coating of $\pi$-conjugated polymer on the surface of latex polymer particles could be achieved even at relatively low $\pi$ conjugated polymer content $(2.9-4.9 \mathrm{wt} \%)$.

\section{REFERENCES}

1. (a) T. A. Skotheim, "Electroresponsive Molecular and Polymeric Systems," Marcel Dekker, Inc., New York, 1991; (b) W. R. Salaneck, D. T. Clark, and E. J. Samuelsen, "Science and Application of Conducting Polymers," Adam Hilger Ltd., Bristol, England, 1991; (c) J. L. Bredas and R. Silbey, "Conjugated Polymers," Kluwer Academic Publishers, Dordrecht, Netherland, 1991; (d) H. Kuzmany, M. Mehring, and S. Roth, "Electronic Properties of Conjugated Polymers," SpringerVerlag, Heidelberg, Germany, 1987.

2. (a) T. Yamamoto, Y. Hayashi, and A. Yamamoto, Bull. Chem. Soc. Jpn., 51, 2091 (1978); (b) T. Yamamoto, K. Sanechika, and A. Yamamoto, J. Polym. Sci., Polym. Lett. Ed., 18, 9 (1980); (c) T. Yamamoto and K. Sanechika, Chem. Ind. (London), 301 (1982). (d) U.S. patent 4,521,589 (1985).

3. M. E. Galvin and G. E. Wnek, Polymer, 23, 795 (1982).

4. T. Yamamoto, A. Morita, T. Maruyama, Z-H. Zhou, T. Kanbara, and K. Sanechika, Polym. J., 22, 187 (1990).

5. S. P. Armes, Synth. Met., 20, 365 (1987).

6. J. I. Kroschwitz, "Electrical and Electronic Properties of Polymers, a State-of-art Compendium," John Wiley \& Sons, New York, N.Y., 1988, p 58.

7. G. E. Wnek, "Electrically Conductive Polymer 
Composites, Handbook of Conducting Polymers," 1986, pp 205-212.

8. D. R. Rueda, M. E. Cagiao, F. J. Balta Calleja, and J. M. Palacios, Synth. Met., 22, 53 (1987).

9. N. V. Bhat and E. Sundaresan, J. Appl. Polym. Sci., 42, 1615 (1991).

10. J. Borgon, W. Behnck, T. Weidenbrueck, and T. Ueno, Synth. Met., 41, 1111 (1991).

11. T. Yoshikawa, S. Machida, T. Ikegami, A. Techagumpuch, and S. Miyata, Polym. J., 22, 1 (1990).

12. E. Ruckenstein and J. S. Park, J. Appl. Polym. Sci., 42, 925 (1991).

13. C-J. Li and Z-G. Song, Synth. Met., 44, 159 (1991).

14. C-J. Li and Z-G. Song, Synth. Met., 40, 23 (1991).

15. M. Morita, I. Hashida, and M. Nishimura, J. Appl. Polym. Sci., 36, 1639 (1988).

16. H. S. O. Chan, T. S. A. Hor, P. K. H. Ho, K. L. Tan, and B. T. G. Tan, J. Macromol. Sci.-Chem., A27, 1081 (1990).

17. M. Aldissi and S. P. Armes, Progress in Organic
Coatings, 19, 21 (1991).

18. A. Yassar, J. Roncali, and F. Garnier, Polym. Commun., 28, 103 (1987).

19. O. Inganas, Br. Polym. J., 20, 233 (1988).

20. L. P. Rector, D. C. De Groot, J. L. Schndler, T. J. Marks, and S. H. Carr, Synth. Met., 41/43, 935 (1991).

21. R. V. Gregory, W. C. Kimbrell, and H. H. Kuhn, Synth. Met., 28, C823 (1989).

22. P. Beadle, S. P. Armes, S. Gottesfeld, C. Mombourquette, R. Houlton, W. D. Andrews, and S. F. Agnew, Macromolecules, 25, 2526 (1992).

23. D. K. Moon, K. Osakada, T. Maruyama, and T. Yamamoto, Makromol. Chem., 193, 829 (1992); T. Yamamoto, Jpn. Patent Appl., 1992-47920.

24. M. B. Inoue, E. F. Velazquez, and M. Inoue, Synth. Met., 24, 223 (1988).

25. A. Pron, M. Zagorska, W. Fabinowski, J. B. Raynor, and S. Lefrant, Polym. Commun., 28, 193 (1987). 